\title{
Sekularita a zápas o veřejný prostor
}

\author{
Secularity and the Struggle over Public Space \\ Ondřej Štěch
}

\begin{abstract}
This article focuses on the debate about the relationship between religion and secularism in the public sphere. It is based on a reconstruction of the theories of John Rawls, Jürgen Habermas and Charles Taylor. In Rawls's theory, the main focus is his concept of public reason, its delimitation against the broader culture, and his proviso which specifies conditions for the introduction of comprehensive doctrines into public reasoning. Habermas replies critically to this concept as too restrictive for religious citizens. This critique reveals his distinction between religious and secular reason, his normative specification of their respective public claims and rights, and finally his idea of their mutual learning. Taylor on the contrary sees any exclusion of religion from public debates as problematic, and sets against it his interpretation of the neutrality of the secular state based on the inclusion of all forms of public expression into debate. In conclusion, the article identifies three key concepts - constitution, reason and recognition - and considers their contribution to the public sphere at the moment when the distinction between religion and secularism itself is questioned.
\end{abstract}

KEYWORDS secularism, religion, public reason, public sphere, John Rawls, Jürgen Habermas, Charles Taylor

Práva a limity náboženství ve veřejném prostoru jsou předmětem intenzivních debat odehrávajících se na pozadí jeho důraznější přítomnosti v politice (Davie 2010). Idea sekulární, racionálně se rozhodující veřejnosti je vystavena zkoušce. Náboženství, navzdory poklesu významu jeho tradičních forem, zůstává součástí politických hnutí a vyžaduje si slyšení. Předpoklady utvářející veřejnost v demokratických státech Západu však nejsou zcela adaptované na „nefiltrovaný“ vstup náboženských aktérů do debaty, a jejich př́ítomnost si proto žádá reflexi.

Cílem tohoto textu je rekonstrukce jedné z debat týkajících se sekularity a náboženství, v níž se střetává několik pohledů na vymezení jejich rolí. Protagonisty této debaty jsou filosofové John Rawls, Jürgen Habermas a Charles Taylor. Polem, na němž se všichni pohybují, je převážně politická filosofie; společné téma ovšem představuje pro každého z nich zároven̆ osobní záležitost, která má hodnotový i emocionální náboj. Zřejmě z tohoto důvodu v jejich rozpravě nalezneme také některá překvapivá nedorozumění, s jejichž pomocí můžeme zahlédnout hlubší, ne zcela artikulované předpoklady jejich teorií. Tyto diskontinuity naznačují, jak ve zralých filosofických koncepcích kondenzují životní zkušenosti a situovanost jejich tvůrců v politických, intelektuálních a náboženských společenstvích.

Sociální studia. Katedra sociologie FSS MU, 3/2013. S. 45-59. ISSN 1214-813X. 
Hlavní část rozboru bude věnována způsobům, jakými rýsují tito tři myslitelé hranice mezi náboženstvím a sekulární veřejností. 1) John Rawls rozlišil zvláštní doménu veřejného rozumu od rozmanitých a neslučitelných učení o světě a místě člověka v něm. Politický liberalismus hledá způsob, jak zabránit kolonizaci prvního druhým, a přitom zajistit všeobecnou volnost projevu v politických diskusích. Hlavním kritériem jsou pro něj základní hodnoty ústavy. 2) Příspěvek Jürgena Habermase se soustředí na analytickou separaci sekulárního a náboženského rozumu jako typů uvažování, které nemohou mít ve veřejném prostoru rovnocenné postavení. Jejich odlišnost je pro něj současně ziskem, nebot' umožňuje vzájemné učení, které může být oboustranně přínosné. 3) Ve své studii o sekulární době se Taylor kriticky staví proti tomuto rozlišení různých druhů racionalit a následně hledá politické řešení, které by zachovalo neutralitu, aniž by se muselo spoléhat na - dle jeho názoru - arbitrární epistemické předpoklady. 4) V závěru pokládám v návaznosti na tyto rekonstrukce dvě související otázky: a) Je samotné vyčlenění náboženství jako zvláštní sféry společenského života udržitelné? b) Pokud nikoli, jaké možnosti nám studované koncepce nabízejí, abychom si mohli představit společenské uspořádání, ve kterém jedinci s odlišným duchovním zázemím dokáží žít v neasimilované různosti a přitom ve vzájemné úctě?

Účastníci zkoumané debaty zároveň patři mezi veřejně činné intelektuály s vlivem na politické myšlení. ${ }^{1}$ Jejich stanoviska byla formulována v propojení s vývojem demokratických společností v Americe i Evropě. Lze je proto interpretovat také jako hluboce promyšlenou reflexi uvedeného vývoje. V ní jsou zachyceny směry myšlení i přetrvávající spory o pochopení základních principů a o jejich vtělení do společenských institucí. Jedním z těchto principů je sekularita veřejného prostoru, tedy odmítnutí hegemonie jakéhokoli náboženství nebo myšlenkového systému. Ačkoli panuje shoda, že je třeba zachovat neutralitu zákonů a oficiálních rozhodnutí, existují též rozdíly týkající se vymezení této neutrality, legitimních opatření k jejímu prosazování či nutnosti zvláštního přístupu k náboženství jako takovému. Filosofická reflexe interpretuje různé odpovědi na tyto základní otázky tak, že hledá koncepty ležící v jejich základu a zasazuje je do širšího rámce ospravedlnění. Význam pro sociologické uchopení sekularizace je v tom, že uvedená reflexe objasňuje předpoklady, z nichž vychází jak debata veřejná, tak také vědecká. Tři základní témata prostupující zkoumanou diskusi, tedy ochrana ústavního uspořádání, role rozumu a jeho vymezení proti ne-rozumu a bezpodmínečné předběžné uznání odlišných pohledů na svět, jsou natolik závažnými předměty sporu, že postoje vůči nim prostupují každé uchopení sekularity. Zároveň se ale jedná o otázky, které nelze kvalifikovaně zodpovědět bez empirického studia náboženství ve veřejném sektoru. Takto představuje tato diskuse v souběhu s ostatními studiemi záležitost zvláštního významu pro podobu západních veřejností, včetně české.

John Rawls je nesporně vůdčí postavou politického myšlení poslední třetiny dvacátého století. Jeho teorie je široce pokládána za nejvlivnější vyjádření sebepojetí liberálních demokracií. Sám se ovšem angažoval v politice pouze okrajově (viz např́íklad rozhovor uveřejněný v Rawls 1999). Naproti tomu Jürgen Habermas vedle své rozsáhlé filosofické práce pravidelně vstupoval do veřejného života, jak podrobně dokumentuje Matuštík (2006). Také Charles Taylor propojuje filosofické bádání s praktickou politickou činností v Québecu i v Kanadě (Mulhall 2004; Bouchard a Taylor 2008). 


\section{John Rawls - veřejnost a její ústava}

Rawlsův vstup do debaty týkající se náboženství a jeho vztahu k veřejné sfére zde budu zkoumat na textech pozdního Rawlsova období, pro které je charakteristickou knihou Political Liberalism (Politický liberalismus) (Rawls 1993). ${ }^{2}$ Jejím záměrem je vymezit ideál demokratické společnosti, v níž občané ,jednají na základě neslučitelných (irreconcilable), ovšem rozumných všeobsažných učení“ (Rawls 1997: 807), přičemž vlastní teorii spravedlnosti jako férovosti (Rawls 1995) v tomto rámci pojímá jako jedno z takových učení. Jeho nejvýraznější teoretické vyjádření přímo k náboženství ${ }^{3}$ se ale nenachází v této knize, nýbrž v článku z roku 1997 „The Idea of Public Reason Revisited“ (Idea veřejného rozumu po revizi; dále IPRR) ${ }^{4}$. Ve své argumentaci budu stavět na analýze tohoto textu a odkazy na další Rawlsovy práce budou sloužit k vyjasnění některých základních pojmů. Rovněž navazující Habermasův příspěvek se odvíjí od stanoviska rozvinutého Rawlsem zde.

Předmětem IPRR je veřejný rozum (public reason), který je ,způsobem uvažování o politických hodnotách sdílených svobodnými a rovnými občany, jenž nezasahuje do sféry všeobsažných učení (comprehensive doctrines) zastávaných občany po dobu, kdy jsou tato učení konzistentní s demokratickým zř́zením“ (Rawls 1997: 807). Důraz je kladen na oddělení obou oblastí, nebot' veřejný rozum ponechává osobní přesvědčení nedotčená; ale zároveň uvidíme překážky, které Rawls staví na ochranu pole, na kterém je tento rozum závazný.

Toto pole je definováno jednak a) úkoly, které veřejný rozum plní, a jednak b) oblastmi působnosti, ve kterých se pohybuje. Do prvního okruhu spadají „hlavní ústavní principy“ (constitutional essentials) a otázky základní spravedlnosti. ${ }^{5}$ Druhý okruh vymezuje oblasti, ve kterých je veřejný rozum závazným zpo̊sobem uvažování. Obecně je shrnuje jako ,veřejné politické fórum“" a specifikuje jeho třri části: 1) řeč (discourse) soudních rozhodnutí, zejména soudců nejvyššího soudu; 2) řeč politiků a vládních úředníků, zvláště na vrcholu výkonné moci a v legislativě; 3) řeč kandidátů na veřejné úřady a manažerů jejich kampaní, ${ }^{6}$ především při jejich veřejných projevech a politických prohlášeních (Rawls 1997: 767). Toto „veřejné politické fórum“ má zvláštní význam, nebot' stanovuje hranici mezi oblastmi, ve kterých je jazyk všeobsažných učení (tedy i náboženství) legitimní, a těmi, ve kterých už jako zdůvodnění nepostačuje. Tato hranice se stala jedním z ústředních témat další diskuse.

Jaký druh řeči, jaké promluvy naplňují charakteristiky veřejného rozumu? Nebo Rawlsovými slovy, co je jeho „obsahem“? Občan na něm participuje tehdy, když vstupuje do rozmluvy

2 Vyšlo též slovensky jako Rawls, John: Politický liberalizmus. Prešov: Slovacontact, 1997.

3 Rawls také napsal krátkou esej On my religion (Rawls 2009), ve které ale poznamenává, že „mé náboženství je zajímavé jenom pro mě samého“; teoretické práce jsou od osobního vztahu maximálně odstíněny. Dá se říci, že Rawls považuje náboženství za analyticky i prakticky oddělitelné od ostatních sfér vnitřního života, a zejména od veřejných názorů.

4 Název poukazuje ke skutečnosti, že se jedná o rozpracování 6. přednášky z Political Liberalism. Veškeré citace z tohoto článku přeložil autor.

5 Mezi tyto základní otázky spravedlnosti patří rozhodování o právu volit, mezích tolerance vůči různým náboženstvím, o tom, kdo má mít zaručené rovné příležitosti či může držet majetek (Rawls 1993: 214, 227-230). Hrubec (2004: 103-109) kritizuje toto pojetí za „sociální deficit“, tedy za vyloučení otázek sociální spravedlnosti z roviny ústavní debaty.

6 Nebot' ti nesou podstatnou zodpovědnost za slova i skutky kandidátů. 
s ostatními z pozic, které sám upřímně považuje za „nejrozumnější politickou koncepci spravedlnosti“. Taková koncepce vyjadřuje politické hodnoty, u kterých lze „,rozumně předpokládat“, že je také ostatní jako svobodní a rovní občané mohou „rozumně přijmout“. Oproti všeobsažným učením charakterizujícím soukromou sféru zde vystupují „,rozumné politické koncepce“, které jsou na rozdíl od nich vzájemně slučitelné, nebot' se zakládají na premisách přijatelných i pro ostatní (Rawls 1997: 773). Veřejné uvažování má za cíl veřejné ospravedlnění, které není „,pouze logicky platnou úvahou, ale argumentem určeným pro druhé“ (Rawls 1997: 786).

Nyní se otevírají dvě důležité otázky. V té první se ptáme, zda je možná nějaká shoda mezi všeobsažnými učeními, nebo jestli je třeba pokaždé překladu do jazyka politické koncepce. Druhou otázku klade sám Rawls takto: „Jak umožnit, aby zastánci náboženského učení založeného na náboženské autoritě - např́iklad církvi nebo Bibli - zastávali současně rozumnou politickou koncepci podporující rozumný ústavní demokratický režim?“" (Rawls 1997: 780).

Na otázku druhou odpovídá Rawls, že to je možné tehdy, pokud náboženské učení dovede nalézt vnitřní zdroje umožňující podporu ústavnímu režimu. Jako příklad uvádí An-Na'imovu (1990) knihu Toward an Islamic Reformation (K islámské reformaci), která směřuje k reinterpretaci práva šari'a kompatibilní s ústavní demokracií. Vnitřním zdrojem je v tomto prŕípadě odkaz na dvě epochy Mohamedova učení, mekkánskou a medinskou, a nadřazení té první jakožto věčného základu božské inspirace islámu. Přičemž obraz dobře uspořádané společnosti načrtnutý v kázání z mekkánského období je podle An-Na'ima nejlépe realizovatelný právě v podmínkách ústavně uspořádané demokracie.

První otázka si potom vyžaduje dvojí odpověd' (viz Skovajsa 2004). Shoda mezi všeobsažnými učeními není jejich hlavním cílem. Je ovšem možné, aby se jejich zastánci vzájemně učili, inspirovali a přesvědčovali se o své loajalitě vůči demokratickému režimu. Neznalost plodí nedůvěru, znalost naopak „občanské přátelství'“.

Neslučitelnost všeobsažných učení ale zůstává nedotčena, z čehož plyne, že „,veřejná politická kultura"7 demokratických společností vyžaduje prezentaci návrhů v jazyce politických koncepcí. Rawls mluví o „podmínce“ (proviso), která musí být naplněna pro náležité uvedení všeobsažného učení do sféry veřejného rozumu. Tato podmínka si zaslouží plné uvedení:

[R]ozumná všeobsažná učení, náboženská i nenáboženská, mohou kdykoli vstoupit do veřejné politické diskuse, pokud v pravý čas poskytnou náležité politické důvody - a nikoli důvody vycházející čistě z všeobsažného učení - dostatečně podepírající cokoli, co tato všeobsažná učení chtějí podpořit. (Rawls 1997: 784-785)

Sféra veřejného rozumu je tedy trvale otevřena jakémukoli rozumnému - tj. slučitelnému s ústavní demokracií - všeobsažnému učení. Jeho důvody ale nemohou být přijaty, pokud svůj záměr nepodepře současně nebo dodatečně také důvody politickými.

„Veřejná politická kultura“ se tímto liší od širší kultury dané společnosti, ve které nepodléhají argumenty uváděné v debatách jakémukoli obsahovému ani formálnímu omezení. Vstup do této užší sféry znamená, že se cílem stává veřejné ospravedlnění a z něj

Veřejná politická kultura se kryje s oblastmi působnosti veřejného rozumu (Rawls 1993: 13-14). Nedemokratické společnosti ji postrádají a nahrazují jinými způsoby rozhodování. 
plynoucí závazek vycházet z politických důvodů, tedy argumentů založených na premisách přijatelných potenciálně také pro druhé lidi. Co z toho plyne pro konkrétní politický projev, je nejzřejmější z príkladů, které Rawls uvádí. Jedním z nich je Hnutí za lidská práva, a zvlášš M. L. King. Jeho řeč byla nezastřeně náboženská, ovšem podmínku naplňovala, nebot' explicitně a v dobré víře podporovala „základní hodnoty ústavy [...], a tím podporovala rozumné politické koncepce“ (Rawls 1997: 785-786, viz též Rawls 1999: 618-620).

Význam podmínky se v tomto světle jeví nikoli jako restrikce, nýbrž co nejširší podpora vstupu všeobsažných učení do veřejného rozvažování demokratické společnosti - při zachování jeho nestrannosti. Důvodem pro podporu je hodnota těchto učení coby „vitálního základu“, který poskytuje politickým koncepcím „,vytrvalou sílu a svěžest“. Kritériem veřejného rozumu musí zůstat ústava a odsud plyne závazek prezentovat jakékoli nároky jako evidentně a srozumitelně slučitelné s hlavními ústavními zásadami. Širší kultura ale přispívá také k rozvoji chápání ústavy. Proto hranice, kterou Rawls staví, stojí nikoli mezi náboženskými a sekulárními učeními, nýbrž mezi veřejným rozumem jako garantem ústavnosti demokracie a všeobsažnými učeními, která spolu tvoří kulturu, zdroj životního smyslu. Ta jsou neslučitelná, ale umožňují vznik „občanského přátelství“ (civic friendship). Veřejnému rozumu poskytují nezbytnou inspiraci, dokud nedojde $\mathrm{k}$ jeho kolonizaci některým z těchto učení. V tomto bodě vstupuje do diskuse Jürgen Habermas a posouvá ji důrazně k otázce náboženství.

\section{Nepřeklenutelný rozdíl: Jürgen Habermas}

Zmíněný posun se odráží již v názvu textu, kterým Habermas (2006) do diskuse vstoupil, totiž Religion in the Public Sphere (Náboženství ve veřejné sféře). ${ }^{8}$ Motivací pro vstup do tohoto terénu jsou významné empirické změny, které lze charakterizovat jako novou politickou důležitost náboženství. To nyní silně zasahuje do národních a etnických konfliktů a vstupuje též do oblasti mezinárodních vztahů - jako v debatě o „multiple modernities“, ve které si velké nezápadní tradice chtějí vydobýt svou vlastní cestu modernizace - často s ohledem na místní náboženské a kulturní tradice. Rovněž Západ zakusil v novém tisíciletí oživení veřejného vlivu náboženských tradic, křest’anských i jiných. Proto si situace žádá nové promyšlení legitimní pozice náboženství a jeho poměru k sekulárnímu státu.

Habermasova argumentace je ukotvena $v$ jeho diskurzivní teorii demokracie (Habermas 1996, 2000). Pravidla politického procesu odvozuje z vnitřních norem rozumné rozpravy, ve které není žádný pohled a návrh zablokován, ovšem současně jsou účastníci zavázáni prezentovat argumenty, které mohou v př́padě potřeby príjatelně obhájit (Habermas 1996: 119). Důraz na komunikativní racionalitu odlišuje Habermasovo pojetí od Rawlse, který se v Politickém liberalismu důsledně soustředí na hodnoty ústavy, která je historicky vzniklým politickým dokumentem. Nikoli tedy manifestem jakéhokoli teoretického konstruktu, nýbrž plodem střetů mezi zastánci rozmanitých teorií a názorů, jako je též jeho vlastní teorie

Text byl také otištěn v European Journal of Philosophy, zde však budu odkazovat na stránkování elektronické verze. 
spravedlnosti. Habermasův pohled přiznává primát teorii, což vede k odlišnému vymezení náboženství a jeho práv.

Nejdříve se vyrovnává s Rawlsovým pojetím obsaženým v IPRR, specificky s ,podmínkou“, kterou zde formuluje pro vstup do veřejného rozvažování. Habermasovo čtení a závěry jsou ovšem překvapivé. Nejprve podmínku vykládá jako pravidlo pro užití „,ne-veřejných, tj. náboženských“ (Habermas 2006: 7) argumentů. Tam, kde se Rawls namáhá, aby zdůraznil rovnost sekulárních i náboženských učení v př́istupu k veřejnému rozumu, Habermas zkratkovitě ztotožní problém s náboženstvím. Následně samotnou podmínku interpretuje v logice svého argumentu jako nepřiměřené břemeno položené nespravedlivě pouze na jednu skupinu občanů, tj. věřících. Zdroje takového výkladu se objasňují v dalším textu; jedním je dezinterpretace Rawlsova chápání veřejného prostoru, druhým potom silný pojem náboženství.

V předchozím oddíle jsem zdůraznil Rawlsovo vícekrát opakované vymezení sféry, kterou někdy označuje za „,veřejný rozum“, jindy za „veřejnou rozpravu“ nebo „kulturu“. Ve všech př́ípadech se jedná o vymezení odlišné od obecného chápání pojmu veřejnosti, a to vymezení, které je výrazně užší. Veřejné užívání rozumu je dle Rawlse závazné jenom v několika institucionálních prostorech, které jsou životně důležité pro zachování ústavního charakteru demokracie. Habermas ovšem pojímá veřejnost jako protiklad soukromé sféry. Potom je pochopitelné, že nepokládá v liberálním státě za přijatelné vyžadovat od všech občanů, aby jakékoli své politické názory zdůvodňovali také „,nezávisle na svých náboženských přesvědčeních“ (Habermas 2006: 9); je možné tvrdit, že ten, před kým hájí věřící občany, není John Rawls.

Fixace na otázku náboženství v interpretaci Rawlse potom plyne z Habermasova silného, totalizujícího obrazu náboženského přesvědčení. Život věřícího člověka je vírou prosycen ve všech každodenních činnostech, je mu zdrojem energie a perspektivou, ze které chce, má a musí pohlížet na všechno, s čím se potká. Naopak sekulární argumenty pro něho nemají žádnou sílu. Proto pro něj představuje nepřijatelné rozdvojení uvažovat o politických otázkách jaksi navíc ještě v sekulárních pojmech (Habermas 2006: 9-10). Současně se náboženská argumentace liší od sekulárních učení (jako kantovství, utilitarismus nebo hegelianismus) v tom, že jakékoli náboženské důvody ,implicitně odkazují ke členství v příslušném náboženském společenství“ (Habermas a Taylor 2011: 61). Tento př́stup, který kombinuje normativní teologické pojetí role víry v životě člověka a silnou představu o vztahu jednotlivce ke společenství věřících, však není př́iliš užitečný pro pochopení, jak mohou věřící občané participovat na veřejném utváření vưle, nebot' valná většina věřících nepojímá každý aspekt svého života exkluzivně v náboženských pojmech, a obecně nelze pokládat silnou niternou víru za jedinou, natož pak dominantní formu náboženské participace (viz např́klad Gill 2001).

Praktické řešení, které Habermas navrhuje, je dovršením nedorozumění, které zde vzniklo. Nebot' aby nebylo pácháno kognitivní násilí na věřících a zároveň byla zachována neutralita státu, je potřeba postavit ,institucionální práh“ tak, aby soudní, legislativní a exekutivní orgány (týká se to též kandidátů do nich) zůstaly prosty ne-sekulárních hlasů, odděleny od „Babylónu“ veřejného života. Podobnost s Rawlsem je nápadná, byt' zde jsou jisté rozdíly. Habermas např́klad požaduje pro předsedu parlamentu právo vyškrtnout jakékoli náboženské výroky ze zápisu jednání (Habermas 2006: 11), zatímco Rawls chce, aby i tyto 
mohly vstoupit „kdykoli“. Habermasova obhajoba role náboženství ve veřejném životě tedy $\mathrm{v}$ tomto případě vedla $\mathrm{k}$ restriktivnějšímu pojetí, než bylo pojetí jím kritizované.

Domnívám se však, že by bylo laciné a nekorektní odbýt Habermasův př́spěvek poukazem na dílčí dezinterpretaci. Těžiště jeho textu leží v koncepci vzájemného učení mezi náboženstvím a sekularitou, čímž se posouvá od otázek politického uspořádání ke zkoumání kognitivních předpokladů demokratické společnosti. Prohlubuje tím Rawlsovu intuici, že pro demokracii je př́nosem čerpat ze zdrojů, které jsou obsaženy v různých učeních zastávaných občany. Habermas je ve své analýze také výrazně citlivější vůči specifikům náboženských a sekulárních pozic a vůči historii jejich vzájemného vymezování.

Pojmem, který je osou uvedeného návrhu, je „obecně př́stupný jazyk“. Ten je více než jenom politickým požadavkem platným ve zmíněných institucionálních prostorech. Habermas ho využívá $\mathrm{k}$ formulování náročnější koncepce soužití a vzájemné komunikace víry a sekulární společnosti. Východiskem je mu taková sekulární filosofie, která si je vědoma limitů rozumu, své omylnosti a nejistoty, ale „trvá na generickém, ale nikterak pejorativně míněném rozlišení mezi sekulární řečí, ve svém nároku všeobecně př́istupnou, a řečí náboženskou, závislou na pravdách zjevení“ (Habermas a Ratzinger 2005: 106). Jak je tento koncept zdůvodněn a proč je relevantní?

Důvody hledání teoretické platformy pro vzájemnou komunikaci náboženství a sekularity jsou dva. První, pozitivní, spočívá v tom, že náboženská tradice může být pro sekulární jazyk obohacením, nebot' $\mathrm{k}$ jeho základním pojmům a intuicím přináší hluboká expresivní vyjádření, která jsou důležitými zdroji smyslu. Aby byl možný takový oboustranný proces učení, musí dojít ke kognitivní adaptaci - věřící musí akceptovat realitu modernity s jejím pluralismem, autoritou vědy a demokratickými procedurami a nevěřící musí být schopni reflektovat limity sekulárního rozumu a také jeho historickou zakotvenost v náboženských učeních. Vytvář́i se společný prostor, ve kterém je možné silné obrazy dobrého života, které plynou z náboženství, podat jazykem všeobecně př́stupným a přesvědčivým, a tedy umožňujícím, aby z nich mohli do jisté míry čerpat všichni občané. Tím demokracie dosahuje hlubší integrace rozmanitých skupin občanů a posiluje svůj normativní základ. Druhým, negativním důvodem tohoto podniku je odmítnutí „,úzkého scientistického konceptu rozumu“ (Habermas 2006: 18), který je v rozporu nejen s náboženstvím, ale i s jakýmkoli porozuměním lidem jako svobodným bytostem. $\mathrm{V}$ jeho rámci nelze morálně zdůvodnit politický život a na něm založené vytváření konsensu - je tedy $\mathrm{v}$ rozporu také s demokracií.

Habermasův př́stup, viditelný v řadě textů zabývajících se vztahem náboženství a sekulárního státu (kromě citovaných také Habermas 2003), prozrazuje vliv evropské kontinentální zkušenosti, pro kterou je typická nedůvěra vůči náboženství, jehož prototypem je anti-liberální integrální katolicismus 19. století. Stát, který má garantovat nestranný přístup ke všem svým občanům, je nucen být především solidní baštou sekulárního rozumu, nepř́stupnou všem pokusům o prosazení partikulárních náboženských světonázorů. Filosofie přiměřená této politice musí trvat na rozlišení mezi sekulární a náboženskou řečí, nebot' to je úhelným kamenem státní neutrality.

Oproti liberalismu Rawlsovu je tato koncepce mnohem méně abstraktní ve vymezení institucionálního veřejného prostoru, nebot' ho explicitně spojuje se sekulárním myšlením. Z toho vyvozuje také sociologické důsledky, když spojuje sekulární a náboženské myšlení 
se skupinami občanů, a poukazuje na odlišné nároky kladené na ně při participaci na veřejné debatě. Rawlsův liberalismus je naopak minimalistický, a pokud jakékoli všeobsažné učení naplňuje kritérium loajality vůči ústavnímu uspořádání, je potom rovné se všemi ostatními. $\mathrm{V}$ „rozumném pluralismu“ hledaném politickým liberalismem nemá např́íklad „spravedlnost jako férovost“ žádné privilegium před ostatními doktrínami; sekulární (ve smyslu „nenáboženská“) povaha není podstatným kritériem politického uspořádání.

Habermas však mapuje jiný terén než Rawls. Pro politické uspořádání společnosti může být studium genealogie náboženství a sekularity nepodstatné, ovšem jakýkoli pokus zmapovat empiricky aktéry veřejného života narazí spiše dř́ve než později na otázky, které si Habermas klade. Stopy historického ustavení současných států lze sledovat na zlomech, které běží např́klad mezi nábožensky nebo etnicky definovanými skupinami. Není přitom žádná záruka, že se shodnou na elementárním vymezení veřejné sféry a státu. V takové situaci pokládá Habermas za nezbytné ztotožnit liberální demokracii se silnou sekulární filosofií a z této pozice hledá alianci s náboženským myšlením, které je ochotno uznat primát sekularity a vstoupit s ní do oboustranně prospěšného vztahu.

Na tomto, řekněme „předpolitickém“, terénu se s Habermasem střetává Charles Taylor, pro něhož je taková specifikace veřejných institucí nepřijatelná. Ačkoliv také sleduje spletité vztahy jednotlivých tradic utvářejících společnosti Západu, odmítá ztotožnění současných demokracií s jedinou z nich, odvozenou od osvícenského humanismu. Uvažuje o uspořádání, které zůstane spravedlivé vůči nárokům všech zainteresovaných skupin a zároveň otevřené k množství nově príichozích účastníků veřejného života, jejichž historie a očekávání nemají nic nebo mají jen málo společného s peripetiemi západních demokracií.

\section{Reflexe a překročení sekularity Charlese Taylora}

Výzvou, se kterou se musí demokratické společnosti vyrovnat, je různost. Nelze očekávat, že pohledy na svět všech aktérů usilujících o účast na veřejném životě budou vzájemně přijatelné. Úkolem státu je potom rovný př́istup ke všem, což ale obnáší řešení nečekaných konfliktů a nutnost občasné redefinice základních principů. Základem Taylorova př́stupu není abstraktní koncepce „rozumných učení“, nýbrž zkoumání konkrétního vývoje duchovní scény Západu. Konceptuální základ tohoto podniku Taylor položil v textech z 80. let (Taylor 1985a, 1985b; srv. Calhoun 1991), a zejména v Sources of the Self (Zdroje já) (Taylor 1989). Zde mapuje postupné „vynalézání“ moderní identity člověka Západu. Každá identita je založena na interpretaci obrazů světa a vlastního místa $\mathrm{v}$ něm, na základě níž jedinec morálně uvažuje a dochází k porozumění (Taylor 1993). Rozhodující pro orientaci v morálním prostoru je vztah $\mathrm{k}$ hodnotám - $\mathrm{k}$ dobru (Hrubec 2001) -, kterými každý poměřje svůj život. Na tomto metodologickém základě stojí též Taylorovo studium moderní sekularity, které je v souhrnné podobě podáno v jeho knize $A$ Secular Age (Sekulární věk) (Taylor 2007). Každý obraz světa je založen na nějakých předpokladech, které nejsou podloženy důkazem,

9 Této knize předcházela série úvah, přednášek a knih, z nichž nejvýznamnější jsou $A$ Catholic Modernity? (Taylor 2001), Varieties of Religion Today (Taylor 2002) a Modern Social Imaginaries (Taylor 2004). 
nýbrž přesvědčením. Přesto se nám mohou jevit sekulární obrazy jako racionálnější než ne-sekulární, nebot' se pohybujeme v široce sdíleném a převážně nereflektovaném „imanentním rámci“ (immanent frame), který naše představy ovlivňuje. Z této perspektivy je normativní nadřazení sekulárních obrazů světa evidentně neuspokojivé. Taylorův normativní návrh se soustředí na hodnoty, které musí sledovat politika férová $\mathrm{k}$ různosti, a zmiňuje některé konflikty, které mohou vznikat mezi těmito hodnotami. Jmenuje tři nejdůležitější, které korespondují se symbolickými základy modernity: svobodu, rovnost a bratrství.

Tématem A Secular Age je hledání kořenů sekularity chápaných jako nové, proměněné „podmínky víry“ (conditions of belief). Inovací evropského novověku je duchovní prostor, který poprvé umožňuje nevěřit $\mathrm{v}$ jakoukoli transcendenci. Nenahrazuje ji však nějakým novým, všezahrnujícím obrazem světa. Místo toho zde dochází $\mathrm{k}$ soužití neslučitelných pohledů na svět, které o sobě vědí a které se vzájemně destabilizují. Nebot' víra v Boha je, stejně jako jakékoli jiné přesvědčení, pouze ,jednou možností mezi jinými“ (Taylor 2007: 3). Tento „duchovní tvar našeho věku“ (Taylor 2007: 539) nazývá Taylor „imanentním rámcem“. Sestává z prolínajících se idejí, zakořeněných představ o společnosti, zažitých praktik a institucí. ${ }^{10}$

Nejvýznamnějšími složkami jsou nové chápání identity a morálního řádu společnosti. Taylor hovoří o ,zapouzdřené“ (buffered) identitě, jejiž nositel odděluje velmi zřetelně vnějšek od vnitřku. Na místo ,porézní“ (porous) identity, která se nemohla bránit mnoha vnějším vlivům a odpovídala magickému světu duchů a démonů, nastupuje identita zapouzdřená, která žije v odkouzlené realitě. Ve zkratce to znamená, že věci vnějšího světa jsou inertní, nemají svůj vnitřní život ani určení, a veškeré duchovní dění se odehrává uvnitř člověka. Ten obrací svůj pohled dovnitř pomocí různých praktik sebereflexe a vnitřní disciplinace. $Z$ tohoto proudu vyrůstá moderní vědomí individuality (Taylor 1989: 111-210). Moderní morální rád je ideál soužití takto individualizovaných lidí. Opouští všechny představy posvátné hierarchie nebo odvěkého zákona a nahrazuje je jediným principem „vzájemného prospěchu“ (mutual benefit) (Taylor 2007: 159nn). Společnost uspořádaná podle něj vytváŕí maximální prosperitu pro všechny své členy, ovšem způsob, jakým to dělá, je až druhotný. Ve vztahu k vnějšímu, materiálnímu světu je tento řád zcela instrumentální.

Vytvoření prostoru individuální niternosti a morálního řádu zaměřeného zcela na světskou prosperitu odbouralo všechny zábrany, které činily z víry v Boha ve středověku prakticky samozřejmost. Naproti tomu imanentní rámec „zakládá ,přirozený řád, stojící v kontrastu proti ,nadpřirozenému', ,imanentní svět v opozici k potenciálně existujícímu ,transcendentnímu““ (Taylor 2007: 542).

Imanentní rámec nevylučuje možnost transcendence, a díky tomu v něm může vůbec vzniknout diskuse mezi náboženstvím a sekulárním myšlením. Nejedná se ovšem o zcela neutrální prostor. Je strukturován tak, že pozice, které transcendenci vylučují, se jeví věrohodnější, „prírozenější'. Jednou z těchto struktur je to, co Taylor nazývá epistemologií. To je obraz lidského poznávání, podle kterého poznáváme nejdříve vnější svět, odděleně od našich názorů, „pozitivně“; až potom můžeme pronášet hodnocení. „Přirozený“ svět je evidentním,

10 Taylor (2007: 212-218) odmítá výklad postavený bud’ na „materiálních“, nebo „ideových“ faktorech; každá nová praxe je ztělesněním nějaké ideje, která zároveň nemůže existovat samostatně. 
všem př́istupným předmětem tohoto poznání, zatímco „nadpřirozený“ je dostupný jenom niterně, soukromě, a nelze o něm přinést přesvědčivé důkazy. Toto je jeden z mechanismů, kterými imanentní rámec podporuje obrazy světa vylučující transcendenci.

Rekonstrukcí vlivů, které působí nerovnováhu mezi náboženskými a sekulárními učeními, chce ovšem Taylor tuto nerovnováhu především delegitimizovat, a v tom se rozchází s Habermasem. Ten usiluje o zachování podstatného rozlišení mezi náboženským a sekulárním myšlením. Jedině druhé z nich může argumentovat v jazyce, který je „obecně př́stupný“, a proto platí všeobecný závazek přijmout sekulární řeč, kdykoli je překročen práh veřejných institucí. Současně chce zachovat „,autentický charakter“ náboženské řeči v neinstitucionálním veřejném prostoru, nebot' má velkou inspirující sílu, plynoucí právě z niterného spojení s životem komunity. Dalo by se říct, že chce náboženství jako služebníka demokracie. Taylor staví všechny druhy pozic, at’ náboženské nebo sekulární, do rovnováhy. Rekonstrukcí imanentního rámce poukazuje na klamnou povahu Habermasova rozlišení. Trvá na tom, že v základu vychází každá pozice z dimenze, která není všeobecně přístupná, z osobní zkušenosti, a její argumenty jsou zakořeněny zde.

Takto formulovaná rovnost mezi všemi pozicemi však vybízí k novému hledání neutrality, nebot' ta zůstává nepostradatelnou součástí legitimity demokratického režimu. Veřejné instituce se musí vyslovovat v „oficiálním“ jazyce, který není zakotven v žádném sporném učení. Zároveň ale $\mathrm{v}$ debatách, které vedou $\mathrm{k}$ oficiálním závěrům, mohou všichni účastníci vycházet $\mathrm{z}$ těch důvodů, které jsou pro ně nejvýznačnější, a z nich vyvozovat své návrhy. V tomto modelu jistě často dojde ke střetu stanovisek, která jsou vzájemně nepřeložitelná. Vyhýbá se však dvojnásobně nepodložené diskriminaci náboženských způsobů řeči, kterou navrhuje Habermas. Za prvé tak, že staví jazyk sekulárních učení jako v principu beze zbytku všeobecně prŕistupný, což Taylor svou analýzou imanentního rámce zpochybňuje. Druhý nepodložený prvek kritizované konstrukce spočívá v samotném rozlišení sekulárního a náboženského jazyka jako kategorií diskursu: je např́íklad „zlaté pravidlo“ náboženské, nebo sekulární? (Taylor 2011: 58).

Střetání neslučitelných stanovisek v sobě jistě obnáší riziko pro veřejnou debatu, ovšem jejich vyloučením z určitých debat se především zbavujeme možnosti je kultivovat. Naopak významným argumentem pro redefinici institucionálních debat v nerestriktivním duchu je podle Taylora čím dál zřetelnější rozpad zavedeného modelu veřejnosti na Západě, spočívajícího na nějakém řešení vztahu křest’anských církví a státu. Trajektorie sekularizace měly samozřejmě odlišnou podobu v jednotlivých státech i regionech, ovšem jejich variabilita byla relativně nízká a předvídatelná. Poslední desetiletí přinesla nástup nových, čím dál rozrůzněnějších a individualizovanějších pozic, které nezapadají příliš dobře do dichotomie náboženství a sekularity, některé z nich přijímají mimoevropské vlivy a celkově dochází k poklesu počtu lidí zařaditelných do kategorií typických pro „první modernu““.11

11 Pro období od otřesů 60. let 20. století razí Taylor (2007: 423-504) označení „věk autenticity“. Ten se liší od předcházející éry „mobilizace“, pro kterou byly charakteristické rozsáhlé instituce, definované národnostně, nábožensky nebo ideologicky. Jeho vymezení je však komplementární se zde užitým Beckovým termínem. 
Významnější proměna však spočívá $\mathrm{v}$ rostoucím počtu a politickém vlivu příchozích ze zemí mimo Evropu, pro které je etablované institucionální uspořádání cizí. Typickým př́íkladem je spor o nošení šátku. Praxe, která má $\mathrm{v}$ rámci islámského světa značnou různorodost a může vyjadřovat více významů, se v Evropě ocitá v novém kontextu, nebot' se stává znamením relativně ohraničené, nábožensky a často etnicky definované skupiny. V konfrontaci s ní se projevuje např́íklad princip laïcité nikoli jako neutrální, nýbrž rovněž kulturně nasycený. ${ }^{12}$ Lpění na formách jeho uplatňování, které vznikaly v 19. a první polovině 20. století, může vést $\mathrm{k}$ situaci, kdy stát kvůli němu přestane být neutrálním prostředníkem a stane se nástrojem etablovaných skupin diskriminujících menšiny kvůli benigním odlišnostem.

Proto usiluje Taylor o formulaci principů, které by umožnily hrát státu neutrální roli, aby mohl být stejně př́stupný všem. Neutralita je komplexním požadavkem, obnáší realizaci nikoli jedné, ale více hodnot (goods): „Můžeme vyzdvihnout tři, které lze rozvrhnout po vzoru francouzské revoluční trojice: volnost, rovnost, bratrství" (Taylor 2011: 34). 1) V oblasti náboženství a základního přesvědčení (basic belief) nesmí docházet k donucení, což obnáší také svobodu nevěřit. 2) Mezi lidmi různých vyznání a přesvědčení musí být rovnost a žádná perspektiva si nemůže nárokovat privilegovaný status, natož aby byla přijata jako státní a závazná. 3) Všechny duchovní komunity musí být vyslyšeny, a to i ve věcech trvalého utváření politické identity a definování režimu práv. Jedním z důsledků takové plurality je možnost konfliktu mezi hodnotami. Uvedený př́klad s „nápadnými náboženskými znameními“ interpretuje Taylor jako střet rovnosti (2), která se projevuje v neutralitě veřejných institucí; proto z nich mají být tyto symboly vyloučeny. Proti tomu stojí svoboda (1), tedy ochrana co nejširšího možného prostoru pro vyjádření a praktikování (v tomto případě) náboženství. Nejedná se tedy o jednoznačný konflikt mezi zastánci sekulárního, neutrálního státu a veřícími, kteří chtějí prosazovat své partikulární hodnoty a neuznávají bariéry, které byly na ochranu neutrality postaveny.

Implikací tohoto rozboru je, že demokracie závisí na silných sdílených předpokladech. Taylor pro ně užívá obecného pojmu „filosofie civility“, zahrnujícího základy občanského soužití. Jádrem jsou tři hodnoty vymezené výše. Proměny veřejnosti, zejména vstup nových aktérů do diskusí o politické identitě, vystavují zavedenou podobu této filosofie zkoušce. Nelze předvídat, $\mathrm{v}$ jaké podobě z ní $\mathrm{v}$ budoucnu vyjde. Lze však říci, že nevhodné restrikce veřejných náboženských projevů nejsou cestou, jak povzbudit důvěru nových skupin občanů v republiky, ve kterých žijí.

\section{Závěr}

Klíčová otázka v těchto souvislostech tedy zní: Jak zachovat hodnoty demokratického společenství, svobodu, rovnost a pluralitu hlasů ve veřejném prostoru, a neohrozit tím politickou stabilitu? Fenomén náboženství vždy představoval pro politiku výzvu, která je patrná na často nesnadném soužití státu a církví. Riziko destabilizace veřejného prostoru se však ještě prohloubilo s rozrůzněním náboženských hlasů v posledních desetiletích.

12 Faktograficky se zde opírám o text Daniele Hervieu-Léger (1998). 
Rekonstrukce jednotlivých odpovědí může začít poukazem na to, co Rawlsův, Habermasův a Taylorův př́stup spojuje. Prvním pojítkem je důraz na neutralitu státu - politická rozhodnutí by měla být zdůvodněna tak, že se nebudou odvolávat na žádné předpoklady, které nejsou všeobecně srozumitelné. Tento požadavek lze formulovat také tak, že všechna rozhodnutí budou všeobecně racionálně přijatelná, ačkoliv s nimi nebude každý souhlasit. Za druhé se všichni tři shodují na právu každého vstoupit se svým př́spěvkem do veřejné debaty. Jedinou zárukou obecné přijatelnosti rozhodnutí je právo každého podílet se na jejich tvorbě. Třetím bodem je obhajoba práva na maximální svobodu v praktikování náboženství a zastávání jakéhokoli přesvědčení.

Nyní se obrátím k rozdílům, které můžeme mezi studovanými pojetími vidět. Tyto rozdíly shrnu pod pojmy charakteristické pro jednotlivé přístupy: ústava, rozum a uznání. Těmito pojmy zachycuji hlavní hodnoty, na kterých tyto př́stupy staví.

Rawlsovou největší starostí je ochrana ústavního uspořádání. Veřejný rozum specifikuje základní náležitosti vztahu ústavní demokratické vlády k občanům a vztahy mezi nimi. Jenom v takovém uspořádání je smysluplná úvaha o pravidlech veřejné debaty oproštěné od „,metafyzických“ předpokladů. V jiných politických režimech může být rozhodující příslušnost ke stejné komunitě nebo snaha „získat svět pro celou pravdu“ (Rawls 1997: 766). V ústavní demokracii panuje mezi občany vzájemná odpovědnost, která je zavazuje k respektu vůči hranici mezi soukromým a veřejným. Ústava je kritériem veřejného života a od ní se odvozuje legitimita různých vstupů do veřejné diskuse. Jakékoli učení má právo vstoupit, pokud byt' implicitně - podporuje základní hodnoty ústavy, a tedy také rozumné politické koncepce. Vztah k ústavě je měřítkem, zda může konkrétní učení usilovat o veřejné ospravedlnění, či nikoli. Tímto důrazem se Rawls opakovaně distancuje od diskriminace náboženských diskursů ve srovnání se sekulárními všeobsažnými učeními.

Odlišuje se tím od Habermasova pojetí, v jehož jádru stojí rozlišení náboženské a sekulární racionality jako kvalitativně odlišných modů. Tímto rozlišením nechce Habermas nikoho zbavovat práv nebo ho vylučovat z veřejné debaty. Vychází však z toho, že způsob řeči pramenící $\mathrm{v}$ náboženské racionalitě je pro veřejné instituce demokratické společnosti nezpůsobilý a musí bezpodmínečně zůstat před jejich prahem. Zároveň uvažuje o využití rozdílu mezi těmito diskursy, nebot' náboženský jazyk může dát sekulárnímu vitální impulsy a přispět k životaschopnosti demokracie. Kvalitou, která předurčuje sekulární rozum k privilegované roli v politickém životě, je „všeobecná přístupnost“ jeho zdůvodnění, plynoucí podle Habermase z faktu, že se neodvozuje od žádné konkrétní komunity a její praxe, nechce prosazovat její perspektivu, ale vede naopak k její transcendenci.

V tomto bodě vstupuje Taylor s námitkou, že korektní vztah sekulárního státu k různorodosti svých občanů nemůže být založen na rozlišení různých druhů racionality. Jeho analýza sekulární doby mimo jiné poukazuje na rovnost mezi všemi pozicemi a druhy racionality, které z nich vycházejí. Neutralita je výkonem, ke kterému směřujeme ve vyjednávání mezi mnoha perspektivami, nikoliv něčím, co by nám bylo dáno jednoduše tak, že určité způsoby řeči vyškrtneme jako nelegitimní. V politickém vyjednávání mají naopak všechny partikulární motivy zaznít, aby bylo možné směřovat k ustavení společného základu. Jedná se nevyhnutelně o složitý a nejistý proces, který je třeba stále znovu opakovat. Vodítkem jsou jedině 
hodnoty, které má demokratické politické společenství realizovat, shrnuté Taylorem jako svoboda, rovnost a bratrství. Okolo nich se utváří „,filosofie civility“.

V Taylorově pojetí je ovšem nadto naznačeno téma, které je pro další rozvoj veřejnosti v demokratických státech rozhodující, totiž krize samotného rozlišení mezi náboženstvím a sekularitou jako jejím protějškem. Tento konstrukt, který je produktem novověkého budování státu a jeho snahy o centralizaci moci, si stále udržuje silný vliv na politickou debatu (Cavanaugh 2009). Rawls se ho ve svém textu snaží maximálně zbavit relevance, aniž by ho však zpochybnil, zatímco pro Habermase je klíčový. Jedině Taylor zde alespoň letmo poukazuje na praktický problém, jak odlišit - na rovině diskursu - náboženskou řeč od sekulární. Tento problém nemusel vyvstat natolik zřetelně, dokud byli jedinými partnery liberální stát a křest’anské církve. Ve chvíli, kdy se začíná duchovní scéna rozrůzňovat nad dosavadní míru, je otřesen také tento konceptuální nástroj kontroly, nebot' mimoevropské kultury nepasují do našich pojmových rámců.

Z idealistického ani pragmatického hlediska není vhodné marginalizovat tyto „nové př́ichozí, kteří již často vůbec př́íchozími nejsou. Jejich názory jsou legitimní součástí veřejné debaty a těžko na ně můžeme uvalovat epistemické rozlišení, které koření v evropských dějinách a má navíc svůj podíl na koloniální epizodě těchto dějin (Chidester 1996). Uspořádání, které by naplnilo nárok otevřenosti vůči těmto novým výzvám a zároveň neobětovalo politickou stabilitu, může hledat inspiraci ve všech třech analyzovaných př́ispěvcích. Rawlsova koncepce klade respekt k základním ústavním hodnotám jako hlavní zdroj stability, aniž by stavěla zásadní omezení způsobu projevu ve veřejné sfére. Naproti tomu je třeba obětovat Habermasovo rozlišení náboženské a sekulární řeči, nebot' se svým dělením podle arbitrárního klíče představuje neopodstatněné břemeno; tato distinkce by měla být $\mathrm{v}$ návaznosti na Taylora zcela rozpuštěna, pokud mají být naplněny hodnoty demokratického státu. V takto změněných podmínkách ovšem získává nový význam étos vzájemného učení a překročení vlastních perspektiv, který prosazují Habermas i Taylor, nebot' ten může vést k hlubší konvergenci názoru na politické hodnoty.

Filosofická diskuse má svůj význam též pro sociálněvědní zkoumání, nebot' rozvíjí argumenty relevantní pro politické ospravedlnění. Empirická zjiššení získávají nový význam, když vstupují do souvislostí debaty o spravedlivém uspořádání té které společnosti, takovém, které má odrážet hodnotové perspektivy různých skupin obyvatel. Zároveň však trvá zřetel na neutralitu a otevřenost veřejnosti i politiky vůči proměňující se společnosti. V krátkosti se jedná o objasňování normativního pojmu sekularity. Z hlediska sociálních věd lze ovšem kriticky podotknout, že filosofické analýzy někdy trpí slabou informovaností o rozmanitých podobách náboženského života a sklouzávají potom $\mathrm{k}$ př́liš rychlému ztotožnění empirických podob náboženství a sekularity s vlastními teoretickými konstrukty. Pro české prostředí, které se bude muset vyrovnat s novou rolí církví ve veřejném prostoru po majetkovém narovnání, obrací diskuse pozornost k podstatným otázkám povahy pluralitního, neutrálního státu, což je zřetel, kterému nebylo dosud věnováno př́iliš prostoru. 


\section{Literatura}

AN-NA'IM, Abdullahi Ahmed. Toward an Islamic Reformation: Civil Liberties, Human Rights and International Law. Syracuse: Syracuse University Press, 1990. ISBN 0-8156-2484-0.

BOUCHARD, Gérard a Charles TAYLOR. Building the Future: A Time for Reconciliation. Québec: Gouvernement de Québec, 2008. ISBN 978-2-550-53401-3.

CALHOUN, Craig. Morality, Identity and Historical Explanation: Charles Taylor on the Sources of the Self. Sociological Theory. 1991, roč. 9, č. 2, s. 232-263. ISSN 1467-9558.

CAVANAUGH, William. The Myth of Religious Violence: Secular Ideology and the Roots of Modern Conflict. Oxford: Oxford University Press, 2009. ISBN 978-0-19-538504-5.

CHIDESTER, David. Savage Systems: Colonialism and Comparative Religion in Southern Africa. Charlottesville: University of Virginia Press, 1996. ISBN 0-8139-1664-X.

DAVIE, Grace. Resacralization. In: TURNER, Bryan S., ed. The New Blackwell Companion to the Sociology of Religion. Oxford: Blackwell, 2010, s. 160-177. ISBN 978-1-4051-8852-4.

GILL, Robin. The Future of Religious Participation and Belief in Britain and Beyond. In: FENN, Richard K., ed. The Blackwell Companion to Sociology of Religion. Oxford: Blackwell, 2001, s. 279-291. ISBN 0-631-21240-X.

HABERMAS, Jürgen. Between Facts and Norms: Contributions to a Discourse Theory of Law and Democracy. Cambridge (MA): MIT Press, 1996. ISBN 978-0-262-08243-3.

HABERMAS, Jürgen. Strukturálni přeměna verejnosti: zkoumáni jedné kategorie občanské společnosti. Praha: Filosofia, 2000. ISBN 80-7007-134-6.

HABERMAS, Jürgen. Víra a vědění. In: HABERMAS, Jürgen. Budoucnost lidské přirozenosti. Praha: Filosofia, 2003, s. 78-93. ISBN 80-7007-174-8.

HABERMAS, Jürgen a Joseph RATZINGER. Předpolitické mravní základy svobodného státu. (Diskusní večer v Bavorské katolické akademii, Mnichov, 19. ledna 2004). Salve. 2005, č. 4, s. 99-117. ISSN 1213-6301.

HABERMAS, Jürgen. Religion in the Public Sphere [online]. 2006 [cit. 1. 7. 2009]. Dostupné z: http:// www.sandiego.edu/pdf/pdf_library/habermaslecture031105_c939cceb2ab087bdfc6df291ec0fc3fa. pdf.

HABERMAS, Jürgen a Charles TAYLOR. Dialogue: Jürgen Habermas and Charles Taylor. In: BUTLER, Judith, Jürgen HABERMAS, Charles TAYLOR a Cornel WEST. The Power of Religion in the Public Sphere. New York: Columbia University Press, 2011, s. 60-69. ISBN 978-0-231-15645-5.

HERVIEU-LÉGER, Danièle. The Past in the Present: Redefining Laïcité in Multicultural France. In: BERGER, Peter L., ed. The Limits of Social Cohesion: Conflict and Mediation in Pluralist Societies. Boulder: Westview Press, 1998, s. 38-83. ISBN 0-8133-3401-2.

HRUBEC, Marek. Východiska Taylorova výkladu ambivalentního charakteru moderny. In: TAYLOR, Charles. Etika autenticity. Praha: Filosofia, 2001, s. 113-132. ISBN 80-7007-150-8.

HRUBEC, Marek. Vrchnostenský veřejný rozum: úskalí politického liberalismu. In: HRUBEC, Marek, ed. Demokracie, veřejnost a občanská společnost. Praha: Filosofia, 2004, s. 91-110. ISBN 80-7007-211-3.

MATUŠTÍK, Martin Beck. Habermasův filosoficko-politický profil. In: MATUŠTÍK, Martin Beck. Neklid doby: filosofické eseje o radikálním zlu a jiných úzkostech dneška. Praha: Filosofia, 2006, s. 37-68. ISBN 80-7007-240-7.

MULHALL, Stephen. Articulating the Horizons of Liberalism: Taylor's Political Philosophy. In: ABBEY, Ruth, ed. Charles Taylor. Cambridge: Cambridge University Press, 2004, s. 105-126. ISBN 978-0-521-80136-2.

RAWLS, John. Political Liberalism. New York: Columbia University Press, 1993. ISBN 0-231-05248-0.

RAWLS, John. Politický liberalizmus. Prešov: Slovacontact, 1997. ISBN 80-88876-01-X. 
RAWLS, John. The Idea of Public Reason Revisited. The University of Chicago Law Review. 1997, roč. 64 , č. 3, s. 765-807. ISSN 1215-1684.

RAWLS, John. Commonweal Interview with John Rawls. In: RAWLS, John. Collected Papers. FREEMAN, Samuel ed. Cambridge (MA): Harvard University Press, 1999, s. 616-622. ISBN 0-674-13739-6.

RAWLS, John. On My Religion. In: RAWLS, John. A Brief Inquiry into the Meaning of Sin and Faith: With On My Religion. Cambridge (MA): Harvard University Press, 2009, s. 259-270. ISBN 978-0-674-03331-3.

SKOVAJSA, Marek. Co umožňuje Rawlsův „překrývající konsensus“, hodnotový pluralismus, nebo homogenita? In: HRUBEC, Marek, ed. Demokracie, veřejnost a občanská společnost. Praha: Filosofia, 2004, s. 111-132. ISBN 80-7007-211-3.

TAYLOR, Charles. Human Agency and Language: Philosophical Papers I. Cambridge: Cambridge University Press, 1985a. ISBN 0-521-26752-8.

TAYLOR, Charles. Philosophy and the Human Sciences: Philosophical Papers II. Cambridge: Cambridge University Press, 1985b. ISBN 0-521-26753-6.

TAYLOR, Charles. Sources of the Self: The Making of the Modern Identity. Cambridge (MA): Harvard University Press, 1989. ISBN 0-674-82425-3.

TAYLOR, Charles. Explanation and Practical Reason. In: NUSSBAUM, Martha a Amartya SEN, eds. The Quality of Life. Oxford: Oxford University Press, 1993, s. 208-232. ISBN 978-0-19-828797-1.

TAYLOR, Charles. A Catholic Modernity? In: HEFT, James L., ed. A Catholic Modernity?: Charles Taylor's Marianist Award Lecture. New York: Oxford University Press, 1999, s. 13-37. ISBN 0-195-13161-4.

TAYLOR, Charles. Varieties of Religion Today: William James Revisited. Cambridge (MA): Harvard University Press, 2002. ISBN 0-674-00760-3.

TAYLOR, Charles. Modern Social Imaginaries. Durham: Duke University Press, 2004. ISBN 978-0-8223-3293-0.

TAYLOR, Charles. A Secular Age. Cambridge (MA): The Belknap Press of Harvard University Press, 2007. ISBN 978-0-674-02676-6.

TAYLOR, Charles. Why We Need a Radical Redefinition of Secularism. In: BUTLER, Judith, Jürgen HABERMAS, Charles TAYLOR a Cornel WEST. The Power of Religion in the Public Sphere. New York: Columbia University Press, 2011, s. 34-59. ISBN 978-0-231-15645-5.

\section{Autor}

Ondřej Štěch se zabývá zkoumáním teorií legitimity sociální integrace v kontextu společenských, politických a kulturních souvislostí. Ve svých analýzách se zaměřuje jednak na pojetí spravedlnosti a demokracie v komunitaristických teoriích, a dále na zkoumání významu pospolitosti pro hodnotovou a sociální integraci. Dalším polem jeho zájmu je teorie dialogu a její uplatnění v interkulturních a mezináboženských souvislostech. Působí na Ústavu sociální práce Univerzity Hradec Králové.

Kontakt: ondrej.stech@gmail.com 